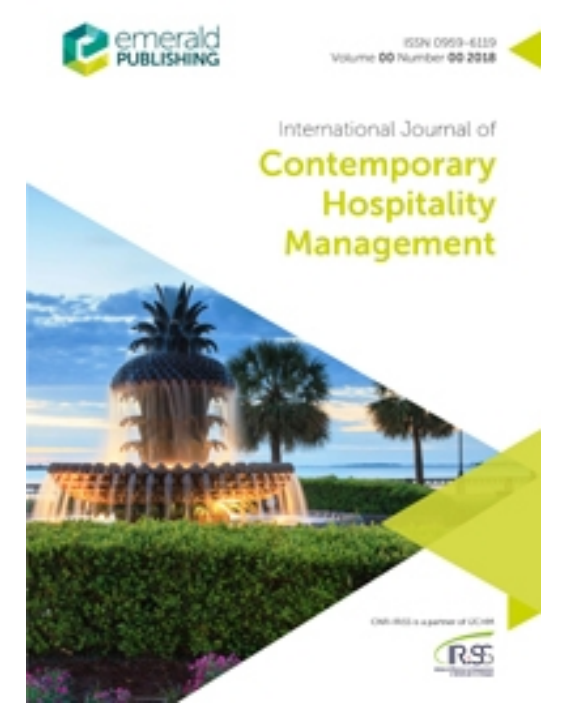

\title{
The role of trip purpose and hotel star rating on guests' satisfaction and WOM
}

\begin{tabular}{|r|l|}
\hline Journal: & International Journal of Contemporary Hospitality Management \\
\hline Manuscript ID & IJCHM-01-2017-0044.R2 \\
\hline Manuscript Type: & Original Article \\
\hline Keywords: & $\begin{array}{l}\text { value for money, Service Quality, WOM recommendation, Guest } \\
\text { satisfaction, Trip purpose, Hotel star rating }\end{array}$ \\
\hline
\end{tabular}

\section{SCHOLARONE ${ }^{m}$ Manuscripts}




\section{The role of trip purpose and hotel star rating on guest satisfaction and WOM}

Submitted: 30 January 2017

$1^{\text {st }}$ Revision: 21 May 2017

$2^{\text {nd }}$ Revision: 12 October 2017

Accepted: 14 October 2017

\section{Abstract \\ Purpose}

The study aims to understand how guests' trip purpose and hotel star rating influence the effects of the value for money perceived at hotels and service quality on guest satisfaction and WOM recommendation.

\section{Design/ Methodology/Approach}

Using TripAdvisor, 25 Singaporean hotels were randomly selected for the study, which yielded hotel reviews from 2040 respondents. Hierarchical and logistic regression analysis was conducted to investigate the relationships proposed in the study.

\section{Findings}

Results indicate significant differences between leisure and business guests' perception of value for money and service quality at hotels with various star ratings. While perceived value for money and service quality were found as significant predictors for both leisure and business guests' satisfaction and WOM, the effects were moderated by the hotel star rating. Despite the significant effect of hotel star rating on guest satisfaction, the study found no significant relationships between hotel star rating and WOM for leisure and business guests.

\section{Practical Implications}

The findings suggest that managers in the hotel industry should understand the purpose of guests' trip and offer services based on their expectations. As the star rating of a hotel creates certain expectations for both leisure and business guests, providing an appropriate level of services and assuring value for money in accordance with the hotel rating, contributes to guest satisfaction and WOM recommendation.

\section{Originality/value}


This study contributes to the hospitality literature by investigating how hotel star rating moderates the relationship of value for money and service quality on leisure and business guests' satisfaction and WOM recommendation.

Key Words: Value for money, service quality, guest satisfaction, WOM recommendation, trip purpose, hotel star rating.

Paper type: Research paper

\section{Introduction}

Understanding consumers is critical to the success of hospitality organisations. Specifically, within the hotel sector, it is advised that all decisions about hotel management should begin with an understanding of guests to determine factors that produce highly satisfied guests (Lu et al., 2015). Maroco and Maroco (2013) emphasize the importance of promoting customer satisfaction and retention to ensure an organisation's long-term financial stability. Oh and Jeong (2010) highlight guest satisfaction to be the basis of competition amongst different organisations within the lodging industry. According to Pizam et al. (2016) customer satisfaction, as the cheapest means of promotion, is necessary for corporate survival.

In their extensive review of published research in the field of hospitality, Line and Runyan (2012) conclude issues pertaining to guest satisfaction to be the most widely pursued, with significant impacts on the organisation's performance and long-term survival. Nevertheless, they emphasize the requirement of future studies on customer satisfaction to identify potential moderators in the relationship. Milfelner et al. (2011) identify a gap in the fields of tourism and hospitality and specifically in the hotel sector in relation to the role of perceived value for money as an antecedent to guests' satisfaction and loyalty.

Moreover, Olorunniwo et al. (2006) emphasize the need to focus on understanding how service quality perceived by customers translate into satisfaction and behavioural outcome. Consequently, the present study aims at analyzing the impact of quality of services offered at hotels and the value for money perceived by hotel guests in achieving satisfaction and behavioral outcome.

Although the literature highlights the importance of perceiving quality services in hotels and realizing value for money with accommodation, the effects of these factors are not necessarily similar for all groups of consumers in perceiving satisfaction (Rajaguru, 2016). 
Arguably in the hotel sector, the effect is more likely to differ based on the guests' trip purpose and the type of accommodation (hotel star rating). This study has chosen the hotel sector in Singapore as the research context.

As guests travelling with different purposes don't have common expectations towards hotels (Radder and Wang, 2006), investigating the roles of perceived service quality and value for money on business and leisure guests' satisfaction is paramount. Radder and Wang (2006) urge future research to compare business and leisure travellers, which could assist hotel managers in satisfying their guests' needs. Similarly, guests' expectation of hotel services often varies based on hotel star rating, which influences the actual service experienced (Tefera and Govender, 2016), thus affecting their overall satisfaction and word of mouth (WOM) recommendations. The difference in service quality and value for money perceived by consumers' in low cost and full-service airlines and their varied effects on customer satisfaction (Rajaguru, 2016), inspired the current study. Hence, the present study aims to investigate how leisure and business travellers' perceive the value for money and quality of services offered at hotels and its influence on their satisfaction and WOM in hotels with different star ratings. The study proposes a conceptual framework that consists of the following constructs: perceived service quality, value for money, guest satisfaction, WOM - as key components of behavioural outcome - as well as the moderating variables of hotel star rating and guests' trip purpose.

The research used data drawn from guests' reviews on TripAdvisor.com in relation to hotels. Schuckert et al. (2015) highlight the significant role played by the internet and online review platforms in influencing both individual buying behaviour and the supply side in the tourism and hospitality industries. Online reviews on value for money perceived at hotel, service quality encountered and satisfaction achieved by guests, increase the visibility of a hotel and contribute to the consumer decision-making process. Tourism and hospitality organisations use online reviews from customers to evaluate and fine-tune their products and services (Phillips et al., 2016; Schuckert et al., 2015; Ye et al., 2011).

The next section presents a review of literature on key constructs and hypotheses development. Then the research methodology and data analysis are presented, followed by the findings. The study concludes by discussing the theoretical and managerial implications as well as limitations and future research directions. 


\section{Literature review}

\subsection{Perceived value for money}

Zeithaml (1988) defines perceived value as "consumer's overall assessment of the utility of a product based on perceptions of what is received and what is given" (p. 14). Others have viewed perceived value in monetary perspectives and explained value for money as the benefits perceived in a product or service compared to the sacrifices made by disbursing the price (Bolton and Drew, 1991; Milfelner et al., 2011). Existing literature discusses perceived value in relation to two dimensions of consumer behaviour: utilitarian where the value is quality perceived for the money paid, and psychological where emotional features affect the perception of value for money (Gallarza and Saura, 2006; Rajaguru, 2016). Most empirical studies examining value for money within the tourism and hospitality field have mainly adopted a utilitarian perspective and simple single-item value scales (Gallarza and Saura, 2006; Kashyap and Bojanic, 2000; Oh, 1999). Chen and Chen (2010) confirm the use of a self-reported unidimensional measure to analyze perceived value for money. As such, a single-item five-point scale was used to assess perceived value for money in this study.

In accordance with the utilitarian dimension, value for money is argued to be driven mainly by price and product/service offerings. A number of studies consider price to have a stronger effect on value perception (Rajaguru, 2016; Varki and Colgate, 2001), while others argue for quality as the leading determinant of perceived value (Cronin et al., 2000; Fornell et al., 1996; Jeong and Jeon, 2008; Milfelner et al., 2011). In either case, perceived value for money contributes to customers' overall satisfaction in different industry contexts (Clemes et al., 2010; Cronin et al., 2000; Gallarza and Saura, 2006; Milfelner et al., 2011; Oh, 1999; Oh and Jeong, 2010; Varki and Colgate, 2001). This is in line with the disconfirmatory paradigm which argues that satisfaction is the difference between expected and perceived value (Milfelner et al., 2011).

Perceived value for money also influences consumers' behavioural outcome (Cronin et al., 2000; Gallarza and Saura, 2006; Milfelner et al., 2011), which in turn could be considered as a predictor of consumers' actual behaviour towards products and services (Azjen and Fishbein, 1980). WOM, purchase intentions, loyalty, and complaining behaviour are the measures of behavioural outcome (Alexandris et al., 2002; Olorunniwo et al., 2006). It is argued that in search of objective opinions, consumers tend to rely on information provided by fellow 
customers rather than business entities, as peer customers are more independent and trustworthy (Haywood, 1989; Schuckert et al., 2015). Therefore, positive WOM is regarded integral to the overall performance of service organisations (Alexandris et al., 2002; Luo and Qu, 2016; Swanson and Hsu, 2011) and thus considered the main component of behavioural outcome in this study.

Within the field of hospitality, perceived value for money is considered an important issue, with previous research confirming perceived value for money as an immediate antecedent to customer satisfaction as well as behavioural outcome (Clemes et al., 2010; Getty and Thompson, 1995; Milfelner and Korda, 2011; Milfelner et al., 2011; Oh, 1999). Line and Runyan (2012) assert that while the perceived value for money has been widely studied in the restaurant sector, its application in other hospitality sectors should be further explored.

Based on the above discussion, we postulate the following hypotheses:

H1: Perceived value for money positively influences (a) leisure guests' and (b) business guests' satisfaction.

H2: Perceived value for money positively influences (a) leisure guests' and (b) business guests' WOM recommendation.

\subsection{Service quality}

Service quality is viewed as an important predictor of success in the hospitality industry. Measured by how well the service at a hotel matches guests' expectations (Parasuraman et al., 1985; Ye et al., 2014), service quality requires continuous feedback from customers (Benitez et al., 2007; Lu et al., 2015; Mohsin and Lockyer, 2010). While the literature suggests different methods to evaluate a hotel's service quality (Lu et al., 2015), a single-item five-point scale was used in this study.

Although considered as distinct concepts, service quality and customer satisfaction are closely related (Holjevac et al., 2009; Torres, 2014). Traditionally, researchers have argued that perception of service quality is built over time from incidents of satisfaction (Bolton and Drew, 1991; Parasuraman et al., 1985). However, they have more recently favoured the view of customer satisfaction as a consequence of service quality (Brady et al., 2002; Carrillat et al., 2009; Clemes et al., 2010; Cronin et al., 2000; Mason and Nassivera, 2013; Torres, 2014). Arguably, the smaller the gap between customers' perceptions and expectations, the better the 
quality of services and thus the higher customer satisfaction (Godolja and Spaho, 2014). Prior travel and tourism studies have identified the significance of service quality in determining customer satisfaction in the contexts of restaurants (Lai, 2015; Namkung and Jang, 2007), airlines (Baker 2013; Rajaguru, 2016), destinations (Tian-Cole and Cromption, 2003; Zabkar et al., 2010) and events/festivals (Mason and Nassivera, 2013; Son and Lee, 2011). Similarly, within the hotel management studies, many empirical studies have investigated service quality as a precedent to guest satisfaction (Choi and Chu, 2001; Clemes et al., 2010; Maroco and Maroco, 2013).

Furthermore, Zeithaml et al. (1996) argue that high perceptions of service quality results in a favourable behavioural outcome. Cronin et al. (2000) reported both a direct and indirect effect of service quality on behavioural outcome in various industries. Similarly, within the hospitality industry, studies have found service quality to positively affect WOM (Alexandris et al., 2002; Ladhari, 2009; Olorunniwo et al., 2006; Su et al., 2016). Therefore, considering the important roles of service quality perceived by consumers, and its potential effect on satisfaction and WOM, we postulate the following hypotheses:

H3: Perceived service quality positively influences (a) leisure guests' and (b) business guests' satisfaction.

H4: Perceived service quality positively influences (a) leisure guests' and (b) business guests' WOM recommendation.

\subsection{Customer satisfaction and WOM}

According to Pizam et al. (2016), customer satisfaction, as a psychological concept, is the positive feeling resulting from gaining what was expected from a product or service. Within the hospitality and tourism research context, the expectancy-disconfirmation theory is the most frequently used concept to explain the relationship between service quality, customer value and customer satisfaction (Oh and Kim, 2017). Based on this theory, confirmation occurs when the outcome of purchasing and using a product or service match expectations. Differences between the expectations and the outcome cause disconfirmation. Negative disconfirmation arises when the product offered performs less than what was expected and positive disconfirmation occurs when it performs better than what was expected. Customers are satisfied when there is confirmation or positive disconfirmation of their expectations (Oliver, 1980; Pizam et al., 2016). 
Consistent with prior studies (e.g. Choi and Chu, 2000; Luo and Qu, 2016; Mey et al., 2006), a single-item five-point scale was used in the present study to assess satisfaction.

Previous research indicates a direct and significant relationship between customer satisfaction and behavioural outcome, specifically WOM (Kumar et al., 2013; Wirtz and Chew, 2002). Comparably, within the hospitality sector, it is argued that satisfied guests are likely to share information about their experiences and make positive recommendations (Clemes et al., 2010; Ladhari, 2009; Luo and Qu, 2016; Pizam et al., 2016; Swanson and Hsu, 2011). Therefore, we hypothesize that:

H5: Guest satisfaction positively influences (a) leisure guests' and (b) business guests' WOM recommendation.

\subsection{Roles of hotel star rating and guests' trip purpose}

The role of hotel star rating and guests' trip purpose on the relationship between value for money, service quality, satisfaction and WOM was investigated in this study:

Insert Figure 1

\subsubsection{Hotel star rating as a moderator}

Hotel rating system is jointly defined by the World Tourism Organisation (UNWTO) and the International Hotel and Restaurant Association (IHRA) as the classes, categories or grades of different accommodation establishments based on their common physical and service characteristics.

Star rating is the most universally recognized hotel rating system (Narangajavana and $\mathrm{Hu}$, 2008). While Ye et al. (2014) argue that hotel star rating could influence guests' perception of service quality, Fernandez and Bedia (2004) conclude that higher star rating does not necessarily indicate better service quality. Nevertheless, it is agreed that four and five star hotels are more luxurious and expensive than lower star hotels in the same location (Guillet and Law 2010; Ye et al., 2014). According to Whitelaw and Jago (2009), both tangible (e.g. value for money) and intangible (service quality) aspects need to be incorporated in star rating systems in order to accommodate guests' expectations as well as meet regulatory requirements. 
Previous research in the hotel sector has focused either on a particular category of hotels (Mohsin and Lockyer, 2010; Rahimi and Kozak, 2016; Ren et al., 2016) or a comparison between different star ratings (Jeong and Jeon, 2008; Oh and Jeong, 2010; Ye et al., 2014). In their study on the effect of hotel accommodation price on the guests' perceived value and service quality, Ye et al. (2014), found the price to have a significant effect on perceived value in higher ranked (star) hotels.

According to Oh and Jeong (2010), four performance variables - room, service, pricevalue, and cleanliness- predicted guests' overall satisfaction across different star ratings. Thus, as the star rating increases, so does guests expectations, and correspondingly their satisfaction. Therefore, we hypothesize that:

H6: Hotel star rating positively influences (a) leisure guests' and (b) business guests' satisfaction.

H7: Hotel star rating positively influences (a) leisure guests' and (b) business guests' WOM recommendation.

H8: Hotel star rating moderates the relationship between value for money and satisfaction of (a) leisure guests and (b) business guests.

H9: Hotel star rating moderates the relationship between service quality and customer satisfaction of (a) leisure guests and (b) business guests.

H10: Hotel star rating moderates the relationship between value for money and WOM recommendation of (a) leisure guests and (b) business guests.

H11: Hotel star rating moderates the relationship between service quality and WOM recommendation of (a) leisure guests and (b) business guests.

\subsubsection{Trip Purpose}

Hotels generally meet the needs of guests with different travel purposes. Oh and Kim (2017) argue that only a limited number of hospitality and tourism researches have studied customer satisfaction from the perspective of trip purpose. Liu et al. (2013) and Radder and Wang (2006) maintain that leisure and business guests' expectations of hotel attributes are more likely to differ. Ye et al. (2014) suggest that trip purpose moderates the impact of price on quality perception. According to them, price does not play a major role for leisure guests but does so for business guests. Also, leisure guests do not directly associate perceived quality to price. 
In their study of leisure and business travellers' choice of hotels, Chu and Choi (2000) found that the preference of these two groups did not differ much in relation to quality and value. In examining the effect of different attributes on customer loyalty in hotels, Ramanathan and Ramanathan (2011) found value for money as a dissatisfier factor for leisure guests and a critical factor for business guests.

While previous research recognizes the combined interaction between work-related and touristic-oriented activities (Uriely, 2001; Unger et al., 2016), the focus of this study is on guests' principal travel purpose as either business or leisure.

\section{Research methodology}

The data used in this study was collected from online hotel reviews on TripAdvisor. Singapore was chosen as the research context as it is a popular hub amongst Asian and non-Asian travellers and caters for both business and leisure travellers (Fontaine, 1999; Lohmann et al., 2009). In 2014, the hotel industry in Singapore experienced a much higher average occupancy rate than the Asia Pacific region (Hargreaves, 2015). All the Singaporean hotels in the dataset were initially categorized into three groups of five, four, three and below three star hotels. Subsequently, hotels in each category were alphabetically arranged and allocated a number. From each category 10 hotels were randomly selected. Hotels which did not represent both leisure and business travellers were excluded from further analysis, ultimately leaving 25 hotels, representing nine, eight and eight hotels from each category of five, four, three and below three star ratings. All those participating in the online review during the six-month study period, starting from February 2015, were considered for the study. Of the 2040 respondents, 620, 980 and 440 were from five, four, three and below three star hotels respectively. Moreover, 1221 of the respondents were leisure and 819 were business travellers.

The data provided information about guests' trip type, i.e., business trip, trip as couples, trip with family, trip with friends, and solo trip. For the purpose of this study, those respondents choosing the last four trip types were categorized as leisure travellers. As respondents were only allowed to select one of the different trip types, the same respondents did not appear in both categories of business and leisure.

\subsection{Data analysis}


Hierarchical multiple regression analysis was employed to assess the interaction effect of hotel start rating with the perceived service quality and value for money in influencing guests' satisfaction (Regression 1). Logistic regression analysis was employed to assess the similar interaction effect on WOM (Regression 2). In model 1, for both multiple regression and logistics regression analyses, the direct effects of value for money and service quality on guest satisfaction were tested. In Model 2 and Model 3, for both multiple regression and logistics regression analyses, the interaction effect of hotel star rating was analyzed. SPSS software was used to conduct the analysis and to test the relationships proposed in the study.

Hotel-stay frequency and country of origin were included as control variables. Frequent guests are considered more knowledgeable about the quality of services offered at the hotels (Min et al., 2002) which influence their satisfaction. According to Zemke et al. (2015), hotel guests' perception of cleanliness and its effect on willingness to pay, differ based on their hotelstay frequency. Similarly, the effect of hotel facilities and service quality on satisfaction varies based on guests' country of origin and culture (Pingitore et al., 2013). To get further insights, separate ad-hoc analyses were performed to test the relationships between the key explanatory variables based on leisure and business guests' hotel-stay frequency as well as their country of origin, categorized into Asian and non-Asian.

\subsection{Non-response bias}

Early and late respondents' responses were compared on key measurement instruments (Armstrong and Overton, 1977; Churchill, 1979) to assure non-response bias. In this study, late respondents were defined as those who provided responses in the review website two weeks after their stay period. Of the total number of respondents, 68\% $(n=1387)$ and $32 \%(n=653)$ were considered as early and late respondents, respectively. The results assured no significant differences between early and late respondents on key variables used in the study.

\subsection{Validity}

The variables of value for money, service quality and guest satisfaction were measured using five-point scale, ranging between 1 and 5 ( $1=$ Low; $5=$ High). WOM was measured as a dichotomous variable $(0=$ not recommend; $1=$ recommend $)$. The study indicated multicollinearity not being an issue, as the Variance Inflation Factor (VIF) among the variables used in the regression model were below 3.0. 


\subsection{Reliability}

As data for the study was collected from an online review website, the reliability of the responses was of concern. Thus, the study compared guest responses in relation to key variables for the same hotels from two review websites; TripAdvisor and Agoda. No significant differences were found between responses from these two review websites on key variables value for money $(\mathrm{t}$ $=.32, p \geq .05)$ and service quality $(\mathrm{t}=.25, p \geq .05)$.

To assure respondent reliability, the key study variables were compared between frequent and non-frequent respondents. Frequent respondents were identified as those who had posted more than 10 reviews, and non-frequent respondents were those with 10 or fewer hotel reviews on TripAdvisor in the previous three years. TripAdvisor also uses the 'quantity' of reviews posted as the basis for distinguishing different reviewer statuses, for instance, those with more than 11 posted reviews are rewarded with a 'contributor' badge (Schuckert et al., 2016). The study found no significant differences between frequent and non-frequent respondents on the key study variables value for money $(\mathrm{t}=.57, p \geq .05)$, service quality $(\mathrm{t}=.32, p \geq .05)$ and guest satisfaction $(\mathrm{t}=.24, p \geq .05)$

Similarly, the study examined the respondents' consistency in responding to key variables by comparing their responses to the variables as well as their detailed comments on the open-ended question. Where mismatches were identified, the respondents were considered disqualified and removed from further analysis. The study removed 56 respondents equivalent to $2.7 \%$ of the total responses.

\section{Findings and discussion}

The direct effect and interaction effects of perceived value for money, service quality and hotel star rating on guest satisfaction are displayed in Table I under Models 1, 2 and 3. Model 1 indicates that the direct effect of value for money (Leisure; $\beta=0.502, p<0.001$; Business: $\beta$ $=0.390, p<0.001$ ) and service quality (Leisure; $\beta=0.398, p<0.001$; Business: $\beta=0.472, p<0.001$ ) on guest satisfaction for both leisure and business guests was positive and significant, thus supporting Hypotheses H1 (a), H1 (b), H3 (a) and H3 (b) (See Table I). The influence of value for money on guests' satisfaction was significantly higher for guests travelling for leisure purposes than those travelling for business purposes. In contrast, the effect of service quality on hotel guest satisfaction was higher for business guests compared to leisure guests. These results 
indicate that leisure guests put more emphasis on value for money while business guests focus more on service quality. The above-mentioned difference could be explained by the fact that business travellers' stay at a hotel is normally paid for by their employers and thus quality, as opposed to value for money, would play a more significant role in their satisfaction. Value for money together with service quality explained $79 \%$ and $70 \%$ of the variance of guest satisfaction for leisure and business guests, respectively.

\section{Insert Table I}

In Model 2, hotel star rating was included as an endogenous variable. The effect of hotel star rating on guest satisfaction was found to be positive and significant for both leisure guests $(\beta=.185, \mathrm{p}<0.001)$ and business guests $(\beta=.125, \mathrm{p}<0.05)$, supporting hypotheses H6 (a) and H6 (b). As hotel bookings for business guests are normally made through corporate travel agents, their involvement in the choice of hotel star rating is significantly less, thus justifying a lower coefficient for such guests compared to leisure guests.

In Model 3, the interaction effect of hotel star rating on the relationship between value for money, service quality and guest satisfaction was investigated for both leisure and business guests. While the interaction effect of hotel star rating and value for money on guest satisfaction was significant for leisure guests $(\beta=-.095, \mathrm{p}<0.001)$; supporting Hypothesis H8 (a), it was not significant for business guests $(\beta=-.172, \mathrm{~ns})$. The negative and significant coefficient indicates that the value for money perceived in higher star hotels negatively influences leisure guests' satisfaction; indicating that such guests get less satisfied with five star hotels compared to four and three and below three star hotels on the basis of value for money. Despite their higher star rating, leisure guests staying in such hotels still compare the received benefits with the sacrifices made, e.g. price paid, when judging the value of the hotel offering (Bolton and Drew, 1991; Milfelner et al., 2011). Similarly, previous research confirms the impact of price on guests' perception of value in higher star rating hotels (Oh and Jeong, 2010; Ye et al., 2014). While the interaction effect of hotel star rating and service quality on guest satisfaction was found to be positive and significant for leisure guests $(\beta=.061, \mathrm{p}<0.05)$, it was negative and significant for business guests $(\beta=-.030, p<0.05)$, thus supporting H9 (a) and H9 (b). The negative coefficient indicates that the service quality perceived from higher star rating hotels negatively influences 
business guests' satisfaction, signifying that such guests get less satisfied with five star hotels. This finding supports previous observations by Fernandez and Bedia (2004), and Oh and Jeong (2010) that guests' expectations generally increase with an increase in the hotel star ratings. Thus, it could be concluded that the effect differs based on the star rating of hotels and across the two different types of guests.

Supporting the moderating effect, Model 3 explained approximately $87 \%$ and $72 \%$ of the variance on leisure and business guests' satisfaction, respectively, which is significantly higher compared to the variances explained in Models 1 and 2.

\section{Insert Table II}

Table II demonstrates the direct effect and interaction effects of the perceived service quality, value for money, and hotel star rating on guests' WOM. Model 1 in Table II indicates that the influence of value for money $(\beta=2.04, p<0.001)$ and service quality $(\beta=1.16, p<0.001)$ on leisure guests' WOM was positive and significant, thus supporting hypotheses H2 (a) and H4 (a). Similarly, the perceived value for money $(\beta=1.57, p<0.001)$ and service quality $(\beta=0.99$, $\mathrm{p}<0.001$ ) had a positive and significant effect on business guests' WOM, supporting Hypothesis $\mathrm{H} 2$ (b) and $\mathrm{H} 4$ (b). The odds ratio indicates that the influence of value for money and service quality on WOM was higher for leisure guests than business guests. This result is supported by the study's previous finding that leisure guests, in general, attach more importance to perceived value for money in evaluating their satisfaction. It is also consistent with previous observations by Ramanathan and Ramanathan (2011) that value for money is a dissatisfier factor for leisure guests.

Including hotel star rating as an additional endogenous factor in the regression analysis (Model 2) resulted in no significant effect of hotel star rating on guests' WOM. Therefore, it can be concluded that despite the significant effect of hotel star rating on guest satisfaction, there are no significant relationships between hotel star rating and WOM for leisure and business guests. Hypotheses H7 (a) and H7 (b) are, thus, not supported. Arguably, guests' intention to recommend a hotel is not based on the hotel star rating but the intrinsic values received from the hotel, including monetary benefit and perceived quality. Hence, the study assessed the interaction effect of hotel star rating across the explanatory variables in Model 3 (value for 
money * hotel star rating, service quality * hotel star rating). The interaction effect of hotel star rating with service quality on WOM for leisure guests indicated a significant relationship ( $\beta=.84$, p $<0.05$ ), supporting Hypothesis H11 (a). The results indicate that leisure guests will recommend the hotel to fellow travellers only if they perceive service quality to be equivalent to the initial expectation they had based on the hotel star rating. The interaction effect of hotel star rating with value for money for business guests demonstrated no significant effect on WOM. Similarly, the interaction effect of hotel star rating with service quality on WOM was not significant. Thus, Hypotheses H10 (b) and H11 (b) are not supported. The significant business guests' perceived value for money and service quality effect on WOM in Model 1 and the nonsignificant interaction effect in Model 3 suggest business guests' hesitance in recommending hotels to others on the grounds of hotel star rating.

In Model 4, customer satisfaction was included as an endogenous variable and the influence of guest satisfaction on WOM was analyzed. As expected, the results showed a positive and significant effect of both leisure $(\beta=1.98, \mathrm{p}<0.001)$ and business guests' $(\beta=1.29$, $\mathrm{p}<0.001$ ) satisfaction on WOM; supporting Hypotheses H5 (a) and H5 (b).

Following the regression results, the interaction effects of hotel star rating with value for money and service quality on guest satisfaction were plotted using Pick-a-Point approach. As suggested by Cohen and Cohen (1983), three simple regression lines of the regression of value for money $\left(\mathrm{X}_{1}\right)$ / service quality $\left(\mathrm{X}_{2}\right)$ on guest satisfaction $(\mathrm{Y})$, as a function of hotel star rating; Low $\left(Z_{L}\right)$, Medium $\left(Z_{M}\right)$ and High $\left(Z_{H}\right)$ were developed. Values of $Z$ were chosen to be one standard deviation (SD) below the mean; at the mean; and above the mean. Using the $\mathrm{Z}$ value, simple regression equations were constructed for leisure and business guests.

$\mathrm{Y}=\beta_{0}+\beta_{1} \mathrm{X}_{1}+\beta_{2} \mathrm{Z}+\beta_{3} \mathrm{X}_{1} \mathrm{Z}$

$Y=\beta_{0}+\beta_{1} X_{2}+\beta_{2} Z+\beta_{3} X_{2} Z$

Insert Figures 2, 3, 4 and 5

The ad-hoc analysis investigating the relationships proposed in the study based on business and leisure guests' hotel-stay frequency indicated significant differences between frequent and non-frequent respondents. Interestingly, the interaction effect of hotel-stay frequency and value for money on satisfaction for leisure guests $(\beta=.112, \mathrm{p}<0.01)$ was found to 
be positive and significant while the interaction effect for business guests $(\beta=.23$, ns) was nonsignificant. The effect of value for money on frequent guests' satisfaction (Leisure: $\beta=.194$, $p<0.001$; Business: $(\beta=.056, n s)$ was higher than that of non-frequent guests (Leisure: $\beta=.147$, $p<0.001$; Business: $(\beta=.076, n s)$. Similarly, the effect of service quality on frequent guests' satisfaction (Leisure: $\beta=.321, p<0.001$; Business: $(\beta=.378, p<0.001)$ was higher than satisfaction for non-frequent guests (Leisure: $\beta=.293, p<0.001$; Business: $(\beta=.311, p<0.001)$. The interaction effect of hotel-stay frequency and service quality on satisfaction was found be significant for both leisure $(\beta=.156, \mathrm{p}<0.001)$ and business guests $(\beta=.133, \mathrm{p}<0.001)$.

An additional ad-hoc analysis investigating the relationships on the basis of business and leisure guests' country of origin indicated significant differences between Asian and non-Asian travellers. The interaction effect of country of origin and value for money on guest satisfaction for both leisure $(\beta=.043, \mathrm{p}<0.01)$ and business guests $(\beta=.013, \mathrm{p}<0.001)$ was found to be nonsignificant. However, the interaction effect of country of origin and service quality on guest satisfaction was found to be significant for both leisure $(\beta=.179, \mathrm{p}<0.001)$ and business guests $(\beta=.085, p<0.01)$. The effect of service quality on guest satisfaction of the Asian leisure travellers $(\beta=.467, \mathrm{p}<0.01)$ was higher than non-Asian leisure travellers $(\beta=.237, \mathrm{p}<0.001)$. On the other hand, the effect for Asian business travellers $(\beta=.198, p<0.01)$ was less than non-Asian business travellers $(\beta=.256, p<0.01)$. Without distinguishing between business and leisure travellers, previous research has identified the higher significance of value for money for Asian travellers and service quality for non-Asian travellers in determining their overall satisfaction (Choi and Chu, 2000; Mey et al., 2006).

\section{Conclusion and implications}

Using data drawn from online reviews on TripAdvisor, this study examined how the value for money and quality of services perceived at hotels with various star ratings influence guest satisfaction and WOM, considering guests' travel purpose. The study contributes to the body of literature in hospitality and specifically in the hotel sector by demonstrating how the hotel star rating and guests' trip purpose moderates the aforementioned relationship.

\subsection{Theoretical Implications}


The study addresses the gap identified by $\mathrm{Wu}$ et al. (2017) on the impact of trip purpose on customer satisfaction by empirically testing leisure and business guests' perception of value for money and service quality at various star hotels. Hence, the study contributes to the expectancydisconfirmation theory (Oliver, 1980) by identifying how different consumer groups' perceptions differ and influence the achievement of satisfaction and WOM.

Extending Choi and Chu's claim (2000) that the influence of service quality on satisfaction is of greater significance in non-Asian travellers, the present study reveals the effect to be greater for non-Asian business guests, as well as Asian leisure guests.

The study also extends the literature on the role of online reviews on consumers' buying behaviour (Phillips et al., 2016; Schuckert et al., 2015) by emphasizing the importance of usergenerated content review websites in capturing hotel guests' perception of service quality, value for money and post-trip reflection.

\subsection{Managerial Implications}

The study provides several practical implications to hotel managers. Considering the study's key findings as well as previous research confirming guests' higher expectations in higher-rating hotels (Fernandez and Bedia, 2004; Oh and Jeong, 2010), hotel managers need to recognise that guests' expectations differ based on their trip purpose and their chosen hotel's star rating. Hence, hotels need to include their points of difference in their positioning strategy and satisfy guests' perceptions of value for money by offering appropriate levels of service. Moreover, given the significant role of trip purpose, hotels need to focus on understanding guests' travel motives to better serve their intended target markets. To achieve higher guest satisfaction and behavioural outcome, hotels could consider positioning themselves as business, leisure, kids friendly or adults only hotels and offer services and prices accordingly. For instance, business travellers are mainly concerned about Internet availability and convenience of hotel location (Banerjee and Chua, 2016; Choi and Chu, 2001), thus requiring hotel managers to focus on these attributes both in their service offerings and promotional activities.

Considering the impact of hotel-stay frequency on both leisure and business guests' perception of service quality and value for money in determining their satisfaction, hotels could consider including questions on their booking forms to understand whether their guests are 
frequent hotel users. Knowing this information, they could then offer incentives and discounts to encourage such guests to write reviews about their stay on online review websites.

Finally, guests' higher satisfaction with lower ranked hotels signifies an opportunity for such hotels to improve their performance; as even a marginal enhancement in perceived value for money and service quality could improve guest satisfaction significantly. Additionally, the differences captured between Asian and non-Asian guests hints at the need for hotels to customize their service offering to guests from various countries and cultures

\subsection{Limitations and Future Research}

The results of the current study are subjected to several limitations, thus highlighting the scope for future research. First, as the study followed cross-sectional design, the inferences are based on associations and not causation. Second, although hotels are encouraged to offer better services to guests, there is ambiguity in distinguishing hotels based on service features. A choice model explaining consumer preference on the combination of price and service quality features in hotels, with different star ratings as well as guests' trip purpose, would better guide the hotel sector in achieving higher guest satisfaction. Third, the use of secondary data in this study did not allow investigating the characteristics of respondents, reasons why they write reviews and the relevant implications. Future research could look into how demographic characteristics, as well as travel experience, i.e., the Travel Career Pattern (Pearce and Lee, 2005), and motivation to post online reviews (Yoo and Gretzel, 2008), contribute to the findings. Fourth, while the current study only investigated business and leisure travellers, prospective research could specifically look into other trip types, i.e., couples, family, friends or solo (Banerjee and Chua, 2016), and the combined work-related and touristic-oriented travel purpose. Finally, the value for money perceived from high yield management hotels is likely to differ from other hotels. Future research could compare the relationships proposed in the study within high yield management hotels.

\section{References}

Alexandris, K., Dimitriadis, N. and Markata, D. (2002), "Can perceptions of service quality predict behavioural intentions? An exploratory study in the hotel sector in Greece", Managing Service Quality: An International Journal, Vol. 12, No. 4, pp. 224-231. 
Armstrong, J.S. and Overton, T.S. (1977), "Estimating nonresponse bias in mail surveys", Journal of Marketing Research, Vol. 14, No. 3, pp. 396-402.

Azjen, I. and Fishbein, M. (1980), Understanding attitudes and predicting social behaviour, Prentice-Hall, Englewood Cliffs, NJ.

Baker, D.A. (2013), "Service quality and customer satisfaction in the airline industry: A comparison between legacy Airlines and low-cost airlines", American Journal of Tourism Research, Vol. 2, No. 1, pp. 67-77.

Banerjee, S. and Chua, A.Y.K. (2016), "In search of patterns among travelers' hotel ratings in TripAdvisor", Tourism Management, Vol. 53, pp. 125- 131.

Benitez, J.M., Martin, J.C. and Roman, C. (2007), "Using fuzzy number for measuring quality of service in the hotel industry", Tourism Management, Vol. 28, No. 2, pp. 544-555.

Bolton, R.N. and Drew, J.H. (1991), "A longitudinal analysis of the impact of service changes on customer attitudes", Journal of Marketing, Vol. 55, No. 1, pp. 1-10.

Brady, M.K., Cronin, J.J. and Brand, R.R. (2002), "Performance-only measurement of service quality: A replication and extension”, Journal of Business Research, Vol. 55, No. 1, pp. 17-31.

Carrillat, F.A., Jaramillo, F. and Mulki, J.P (2009), "Examining the impact of service quality: A meta-analysis of empirical evidence", Journal of Marketing Theory and Practice, Vol. 17, No. 2, pp. 95-110.

Chen, C.F. and Chen, F.S. (2010), "Experience quality, perceived value, satisfaction and behavioural intentions for heritage tourists", Tourism Management, Vol 31, No. 1, pp. 29-35.

Choi, T.Y. and Chu, R. (2000), "Levels of satisfaction among Asian and Western travelers", International Journal of Quality \& Reliability Management, Vol. 17, No. 2, pp.116-132.

Choi, T.Y. and Chu, R. (2001), "Determinants of hotel guests' satisfaction and repeat patronage in the Hong Kong hotel industry", Hospitality Management, Vol. 20, pp. 277-297.

Chu, R.K.S. and Choi, T. (2000), “An importance-performance analysis of hotel selection factors in the Hong Kong hotel industry: A comparison of business and leisure travelers", Tourism Management, Vol. 21, No. 4, pp. 363-377.

Chua, B., Lee, S. and Han, H. (2017), "Consequences of cruise line involvement: a comparison of first-time and repeat passengers", International Journal of Contemporary Hospitality Management, Vol. 29, No. 6, pp. 1658-1683.

Churchill Jr, G.A. (1979), “A paradigm for developing better measures of marketing constructs”, Journal of Marketing Research, Vol. 16, No. 1, pp. 64-73.

Clemes, M.D., Gan, C. and Ren, M. (2010), "Synthesizing the effects of service quality, value, and customer satisfaction on behavioural intentions in the motel industry: An empirical analysis", Journal of Hospitality and Tourism Research, Vol. 35, No. 4, pp. 530-568.

Cohen, J. and Cohen, P. (1983), Applied multiple regression/ correlation analysis for the behavioral sciences. Hillsdale, NJ: Erlbaum 
Cronin, J.J., Brady, M.K. and Hult, G.T. (2000), "Assessing the effects of quality, value, and customer satisfaction on consumer behavioural intentions in service environments", Journal of Retailing, Vol. 76, No. 2, pp. 193-218.

Fernandez, M.C.L. and Bedia, A.M.S. (2004), "Is the hotel classification a good indicator of hotel quality? An application in Spain”, Tourism Management, Vol. 25, pp. 771-775.

Fontaine, G. (1999). "Singapore, tourism and world", Asia Pacific Journal of Tourism Research, Vol. 4, No. 1, pp. 30-38.

Fornell, C., Johnston, M.D., Anderson, E.W., Cha, J. and Bryant, B.E. (1996), "The American Customer Satisfaction Index: Nature, purpose, and findings", Journal of Marketing, Vol. 60, No. 4, pp. 7-18.

Gallarza, M.G. and Saura, I.G. (2006), "Value dimensions, perceived value, satisfaction and loyalty: An investigation of university students' travel behaviour", Tourism Management, Vol. 27, No. 3, pp. 437-452.

Godolja, M. and Spaho, A. (2014), "Critical incident analysis in measurement of hotel guest satisfaction. A case study from Tirana, Albania", Journal of Educational and Social Research, Vol. 4, No. 4, pp. 437-441.

Guillet, B.D. and Law, R. (2010), "Analyzing hotel star ratings on third-party distribution websites", International Journal of Contemporary Hospitality Management, Vol. 22, No. 6, pp. 797-813.

Hargeraves, C.A. (2015), "Analysis of hotel guest satisfaction ratings and reviews: An application in Singapore", American Journal of Marketing Research, Vol. 1, No. 4, pp. 208-214.

Haywood, K.M. (1989), "Managing word of mouth communications", Journal of Services Marketing, Vol. 3, No. 2, pp. 55-67.

Holjevac, I.A., Markovic, S. and Raspor, S. (2009), "Customer satisfaction measurement in hotel industry: content analysis study", Paper presented at the 4th International Scientific Conference on Planning for the Future Learning from the Past: Contemporary Developments in Tourism, 35 April 2009, Travel \& Hospitality, Rhodes Island, Greece, available at: https://www.researchgate.net/publication/228466590_Customer_Satisfaction_Measurement_In Hotel_Industry_Content_Analysis_Study, accessed 20 January, 2017.

Jeong, M. and Jeon, M.M. (2008), "Customer reviews of hotel experiences through consumer generated media (CGM)", Journal of Hospitality \& Leisure Marketing, Vol. 17, No. 1-2, pp. 121-138.

Kashyap, R. and Bojanic, D.C. (2000), "A structural analysis of value, quality, and price perceptions of business and leisure travelers", Journal of Travel Research, Vol. 39, No. 1, pp. 45-51.

Kumar, V., Pozza, I.D. and Ganesh, J. (2013), "Revisiting the satisfaction-loyalty relationship: Empirical generalizations and directions for future research", Journal of Retailing, Vol. 89, No. 3, pp. 246-262.

Ladhari, R. (2009), "Service quality, emotional satisfaction, and behavioral intentions", Managing Service Quality: An International Journal, Vol. 19, No. 3, pp. 308-331. 
Lai, I.K.W. (2015), "The roles of value, satisfaction, and commitment in the effect of service quality on customer loyalty in Hong Kong-style tea restaurants", Cornell Hospitality Quarterly, Vol. 56, No. 1, pp. 118-138.

Line, N.D. and Runyan, R.C. (2012), "Hospitality marketing research: Recent trends and future directions", International Journal of Hospitality Management, Vol. 31, No. 2, pp. 477-488.

Lohmann, G., Albers, S., Koch, S. and Pavlovich, K. (2009), "From hub to tourist destination an explorative study of Singapore and Dubai's aviation-based transformation", Journal of Air Transport Management, Vol. 15, No. 5, pp. 205-211.

Lu, C., Berchoux, C., Marek, M.W. and Chen, B. (2015), "Service quality and customer satisfaction: Qualitative research implications for luxury hotels", International Journal of Culture, Tourism and Hospitality Research, Vol. 9, No. 2, pp. 168-182.

Luo, Z. and Qu, H. (2016), "Guest-defined hotel service quality and its impacts on guest loyalty”, Journal of Quality Assurance in Hospitality \& Tourism, Vol. 17, No. 3, pp. 311-332.

Maroco, A.L. and Maroco, J. (2013), "Service quality, customer satisfaction and loyalty in 4and 5- star hotels", European Journal of Hospitality, Tourism and Recreation, Vol. 4, No. 3, pp. 119-145.

Mason M.C. and Nassivera, F. (2013), "A conceptualization of the relationships between quality, satisfaction, behavioural intention, and awareness of a festival", Journal of Hospitality Marketing and Management, Vol. 22, No. 2, pp. 162-182.

Mey, L.P., Akbar, A.K. and Fie, D.Y.G. (2006), "Measuring service quality and customer satisfaction of the hotels in Malaysia: Malaysian, Asian and non-Asian hotel guests", Journal of Hospitality and Tourism Management, Vol. 13, No. 2, pp. 144-160.

Milfelner, B., Snoj, B. and Korda, A.P. (2011), "Measurement of perceived quality, perceived value, image and satisfaction interrelations of hotel services: Comparison of tourists from Slovenia and Italy", Social Research - Journal for General Social Issues, Vol. 3, pp. 605-624.

Milfelner, M. and Korda, A.P. (2011), "Hotel image and guests satisfaction as a source of sustainable competitive advantage”, International Journal of Sustainable Economy, Vol. 3, No. 1, pp. 92-106.

Min, H., Min, H. and Emam, A. (2002), "A data mining approach to developing the profiles of hotel customers", International Journal of Contemporary Hospitality Management, Vol. 14, No. 6, pp.274-285.

Mohsin, A. and Lockyer, T. (2010), "Customer perceptions of service quality in luxury hotels in New Delhi, India: An exploratory study", International Journal of Contemporary Hospitality Management, Vol. 22, No. 2, pp. 160-173.

Namkung, Y. and Jang. S. (2007), "Does food quality really matter in restaurants? Its impact on customer satisfaction and behavioural intentions", Journal of Hospitality \& Tourism Research, Vol. 31, No. 3, pp. 387-410.

Narangajavana, Y. and Hu, B. (2008), “The relationship between the hotel rating system, service quality improvement, and hotel performance changes: A canonical analysis of hotels in Thailand", Journal of Quality Assurance in Hospitality and Tourism, Vol. 9, No. 1, pp. 34-56. 
Oh, H. (1999), "Service quality, customer satisfaction, and customer value: A holistic perspective”, International Journal of Hospitality Management, 18(1), pp.67-82.

Oh, H. and Jeong, M. (2010), "Evaluating stability of the performance-satisfaction relationship across selected lodging", International Journal of Contemporary Hospitality Management, Vol. 22, No. 7, pp. 953-974.

Oh, H. and Kim, K. (2017), "Customer satisfaction, service quality, and customer value: years 2000-2015 ", International Journal of Contemporary Hospitality Management, Vol. 29, No.1, pp. 2-29.

Oliver, R.L. (1980), "A cognitive model of the antecedents and consequences of satisfaction decisions", Journal of Marketing Research, Vol. 17; No.4, pp. 460-469.

Olorunniwo, F., Hsu, M.K. and Udo, G.J. (2006), "Service quality, customer satisfaction, and behavioural intentions in the service factory", Journal of Services Marketing, Vol. 20, No.1, pp. 59-72.

Parasuraman, A., Zeithaml, V. and Berry, L. (1985), “A conceptual model of service quality and its implications for future research", Journal of Marketing, Vol. 49, No. 4, pp. 41-50.

Pearce, P.L. and Lee, U. (2005), "Developing the travel career approach to tourist motivation", Journal of Travel Research, Vol. 43, No. 3, pp. 226-237.

Phillips, P., Barnes, S., Zigan, K. and Schegg, R. (2016), "Understanding the impact of online reviews on hotel performance: An empirical analysis", Journal of Travel Research, Vol. 56, No.2, pp. 235-249.

Pingitore, G., Huang, W. and Greif, S. (2013), "Lost in translation: Cross-country differences in hotel guest satisfaction", Cornell Hospitality Industry Perspectives, Vol. 3, No. 2, pp. 6-14.

Pizam, A., Shapoval, V. and Ellis, T. (2016), "Customer satisfaction and its measurement in hospitality enterprises: A revisit and update", International Journal of Contemporary Hospitality Management, Vol. 28, No. 1, pp. 2-35.

Radder, L. and Wang, Y. (2006), "Dimensions of guest house service managers' perceptions and business travelers' expectations", International Journal of Contemporary Hospitality Management, Vol. 18, No.7, pp. 554-562.

Rahimi, R. and Kozak, M. (2016), "Impact of customer relationship management on customer satisfaction: The case of a budget hotel chain", Journal of Travel \& Tourism Marketing, Vol.34, No.1, pp. 40-51.

Rajaguru, R. (2016), "Role of value for money and service quality on behavioural intention: A study of full service and low cost airlines", Journal of Air Transport Management, Vol. 53, pp. 114-122.

Ramanathan, U. and Ramanathan, R. (2011), "Guests' perceptions on factors influencing customer loyalty", International Journal of Contemporary Hospitality Management, Vol. 23, No.1, pp. 7-25. 
Ren, L., Qiu, H., Wang, P. and Lin, P.M.C. (2016), "Exploring customer experience with budget hotels: Dimensionality and satisfaction", International Journal of Hospitality Management, Vol. 52, pp. 13-23.

Schuckert, M., Liu, X. and Law, R. (2015), "Hospitality and tourism online reviews: Recent trends and future directions", Journal of Travel \& Tourism Marketing, Vol. 32, No. 5, pp. 608621.

Schukert, M., Liu, X. and Law, R. (2016), "Stars, votes, and badges: How online badges affect hotel reviewers", Journal of Travel \& Tourism Marketing, Vol. 33, No. 4, pp. 440-452.

Son, S.M. and Lee, K.M. (2011), "Assessing the influences of festival quality and satisfaction on visitor behavioural intentions”, Event Management, Vol. 15, No. 3, pp. 293-303.

Su, L., Swanson, S.R. and Chen, X. (2016), "The impact of perceived service fairness and quality on the behavioral intentions of Chinese hotel guests: The mediating role of consumption emotions", Journal of Travel \& Tourism Marketing, Vol. 33, pp. 88-102.

Swanson, S.R. and Hsu, M.K. (2011), "The effect of recovery locus attributions and service failure severity on word-of-mouth and repurchase behaviours in the hospitality industry", Journal of Hospitality \& Tourism Research, Vol. 35, No. 4, pp. 511-529.

Tefera, O. and Govender, K. (2016), "Hotel ratings, service quality, customer satisfaction and loyalty: The perception of guests at Ethiopian hotels", African Journal of Hospitality, Tourism and Leisure, Vol. 5, No. 3, pp. 1-23

Tian-Cole, S. and Cromption, J. (2003), "A conceptualization of the relationships between service quality and visitor satisfaction, and their links to destination selection", Leisure Studies, Vol. 22, No. 1, pp. 65-80,

Torres, E.N. (2014), "Deconstructing service quality and customer satisfaction: Challenges and directions for future research", Journal of Hospitality Marketing \& Management, Vol. 23, No. 6, pp. 652-677.

Unger, O., Uriely, N. and Fuchs, G. (2016), “The business travel experience”, Annals of Tourism Research, Vol. 61, pp. 142-156.

Uriely, N. (2001), “Travelling workers' and 'working tourists': Variations across the interaction between work and tourism”, The International Journal of Tourism Research, Vol. 3, pp. 1-8.

Varki, S. and Colgate, M. (2001), "The role of price perceptions in an integrated model of behavioural intentions", Journal of Service Research, Vol. 3, No. 1, pp. 232-240.

Whitelaw, P.A. and Jago, L.K. (2009), Understanding the key elements of star ratings in accommodation, Cooperative Research Centre for Sustainable Tourism, Australia. ISBN: 9781921521911.

Wirtz, J. and Chew, P. (2002), "The effects of incentives, deal proneness, satisfaction and tie strength on word-of-mouth behavior", International Journal of Service Industry Management, Vol. 13, No. 2, pp. 141-162. 
Wu, M., Pearce, P. and Dong, W. (2017), "How satisfying Shanghai's superior hotels? The view of international tourists, International Journal of Contemporary Hospitality Management, Vol. 29, No. 4, pp. 1096-1115.

Ye, Q., Li, H., Wang, Z. and Law, R. (2014), "The influence of hotel price on perceived service quality and value in e-tourism: An empirical investigation based on online traveler review", Journal of Hospitality \& Tourism Research, Vol. 13, No. 1, pp. 23-39.

Ye, Q., Law, R., Gu, B. and Chen, W. (2011), "The influence of user-generated content on traveler behaviour: An empirical investigation on the effects of e-word-of-mouth to hotel online bookings", Computers in Human Behaviour, Vol. 27, No. 2, pp. 634-39.

Yoo, K.H. and Gretzel, U. (2008), "What motivates consumers to write online travel reviews?", Information Technology \& Tourism, Vol. 10, No. 4, pp. 283-295.

Zabkar,V., Brencic, M.M. and Dmitrovic, T. (2010), "Modelling perceived quality, visitor satisfaction and behavioural intentions at the destination level", Tourism Management, Vol. 31, No. 4, pp. 537-546.

Zeithaml, V.A., Berry, L.L. and Parasuraman, A. (1996), "The behavioral consequences of service quality"', Journal of Marketing, Vol. 60, pp. 31-46.

Zeithaml, V.A. (1988), "Consumer perceptions of price, quality, and value: a means-end model and synthesis of evidence", Journal of Marketing, Vol. 52, No. 3, pp. 2-22.

Zemke, D.M.V., Neal, J., Shoemaker, S. and Kirsch, K. (2015), "Hotel cleanliness: will guests pay for enhanced disinfection?", International Journal of Contemporary Hospitality Management, Vol. 27, No. 4, pp. 690-710. 
Figure 1: The Conceptual Framework

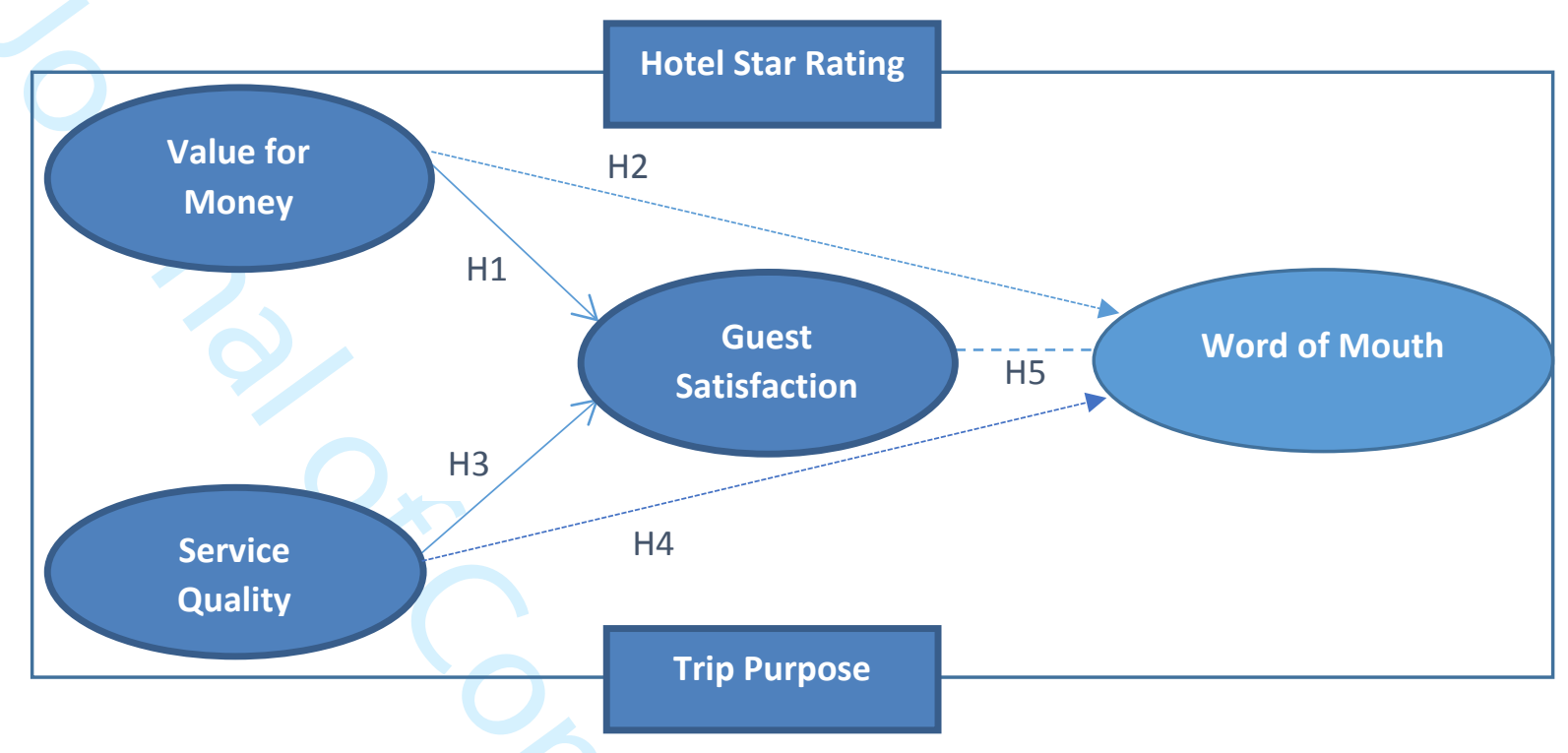

25

26 
Figure 2: Interaction effect of value for money and hotel star rating on customer satisfaction: Leisure guests' perspectives

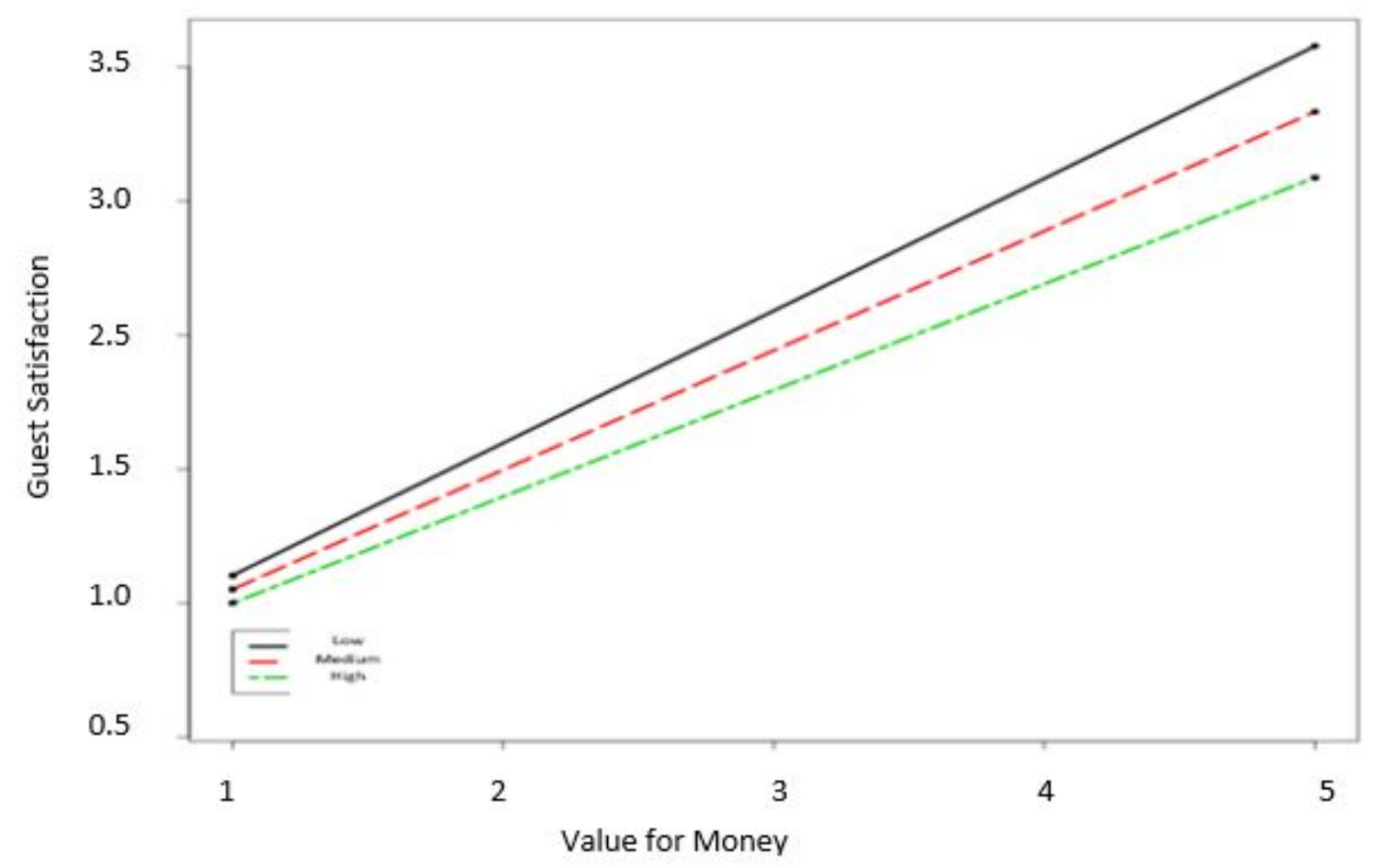

Figure 3: Interaction effect of service quality and hotel star rating on customer satisfaction: Leisure guests' perspectives

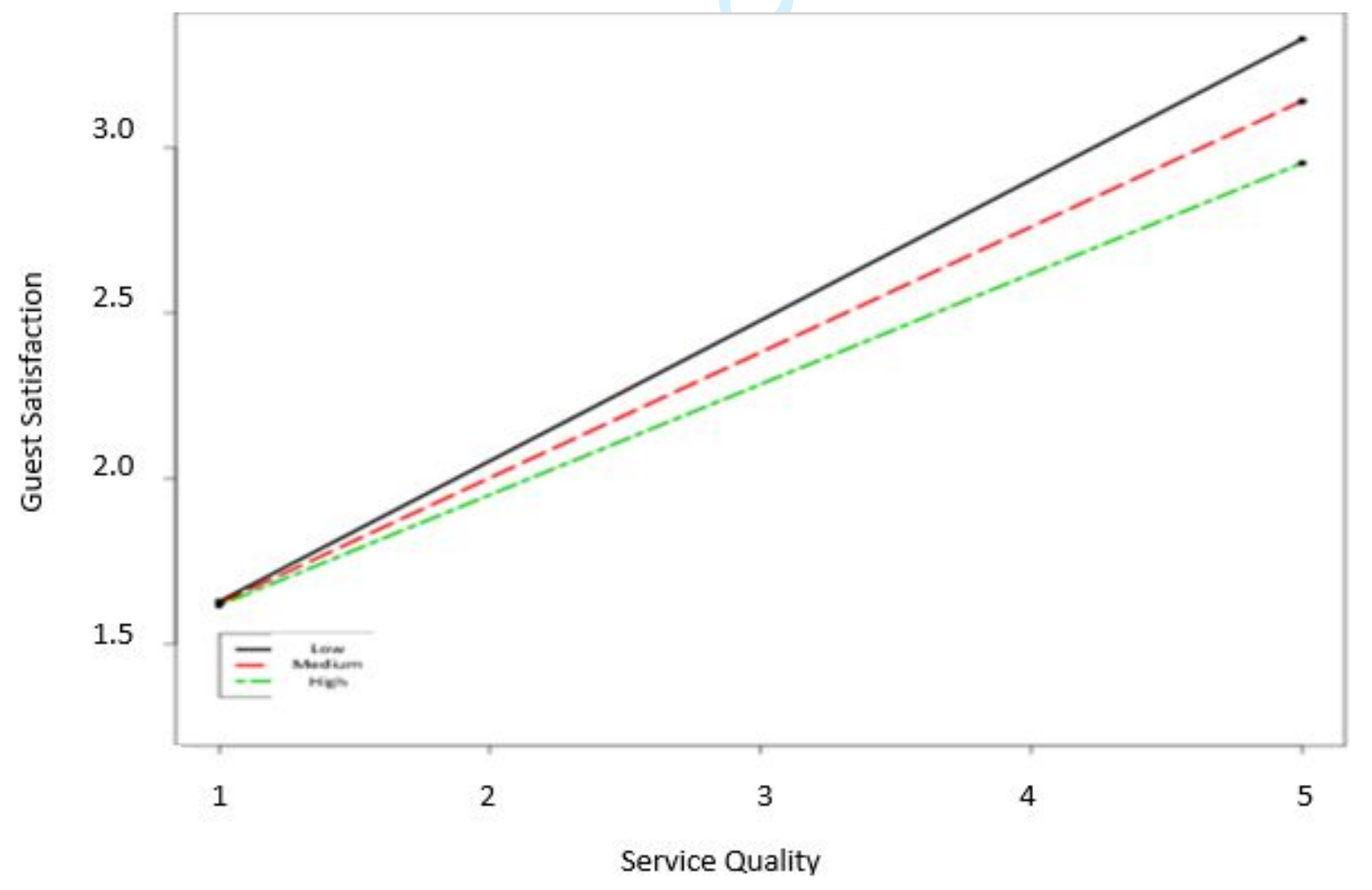


Figure 4: Interaction effect of value for money and hotel star rating on customer satisfaction: Business guests' perspectives

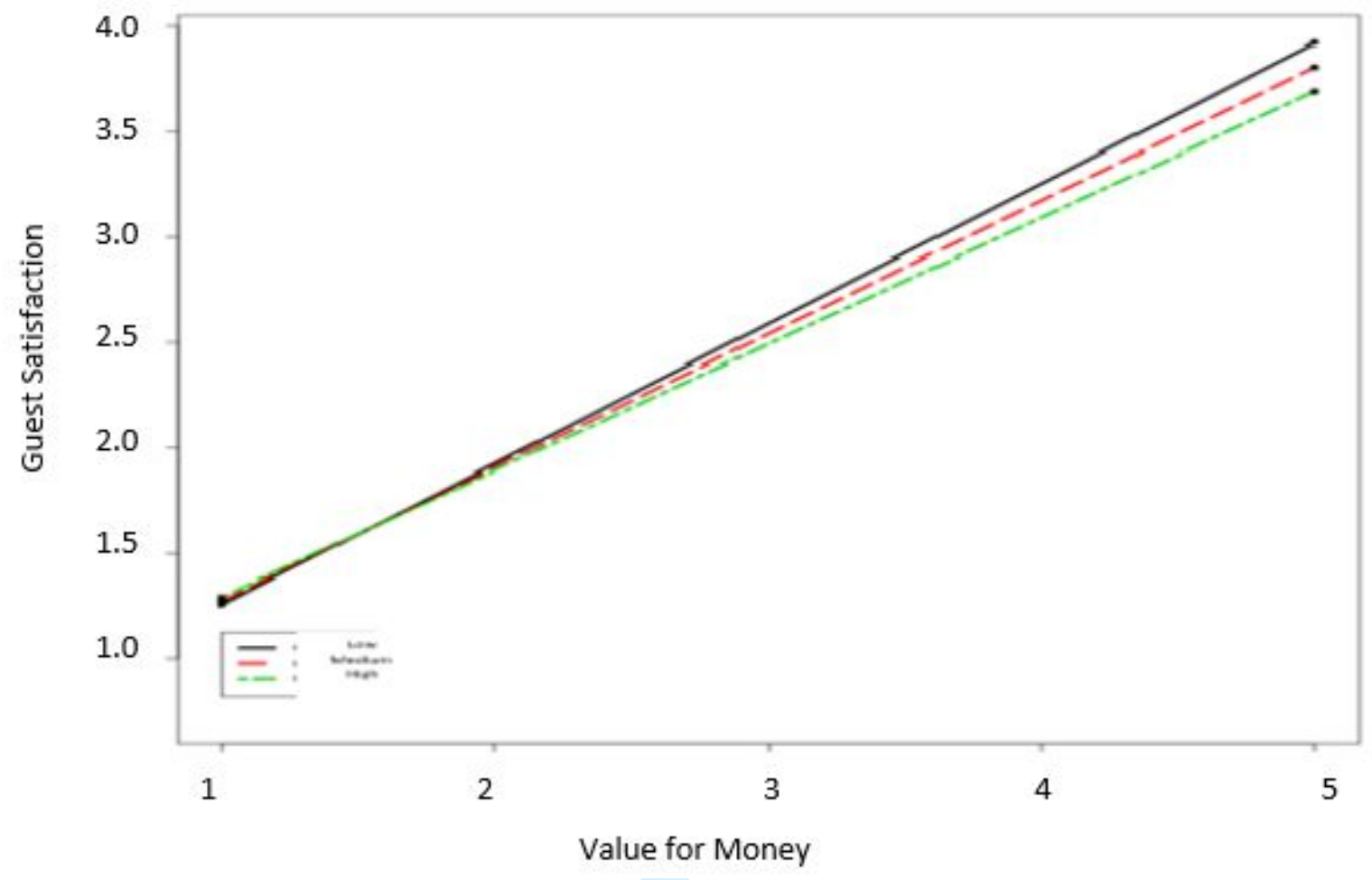

Figure 5: Interaction effect of service quality and hotel star rating on customer satisfaction: Business guests' perspectives

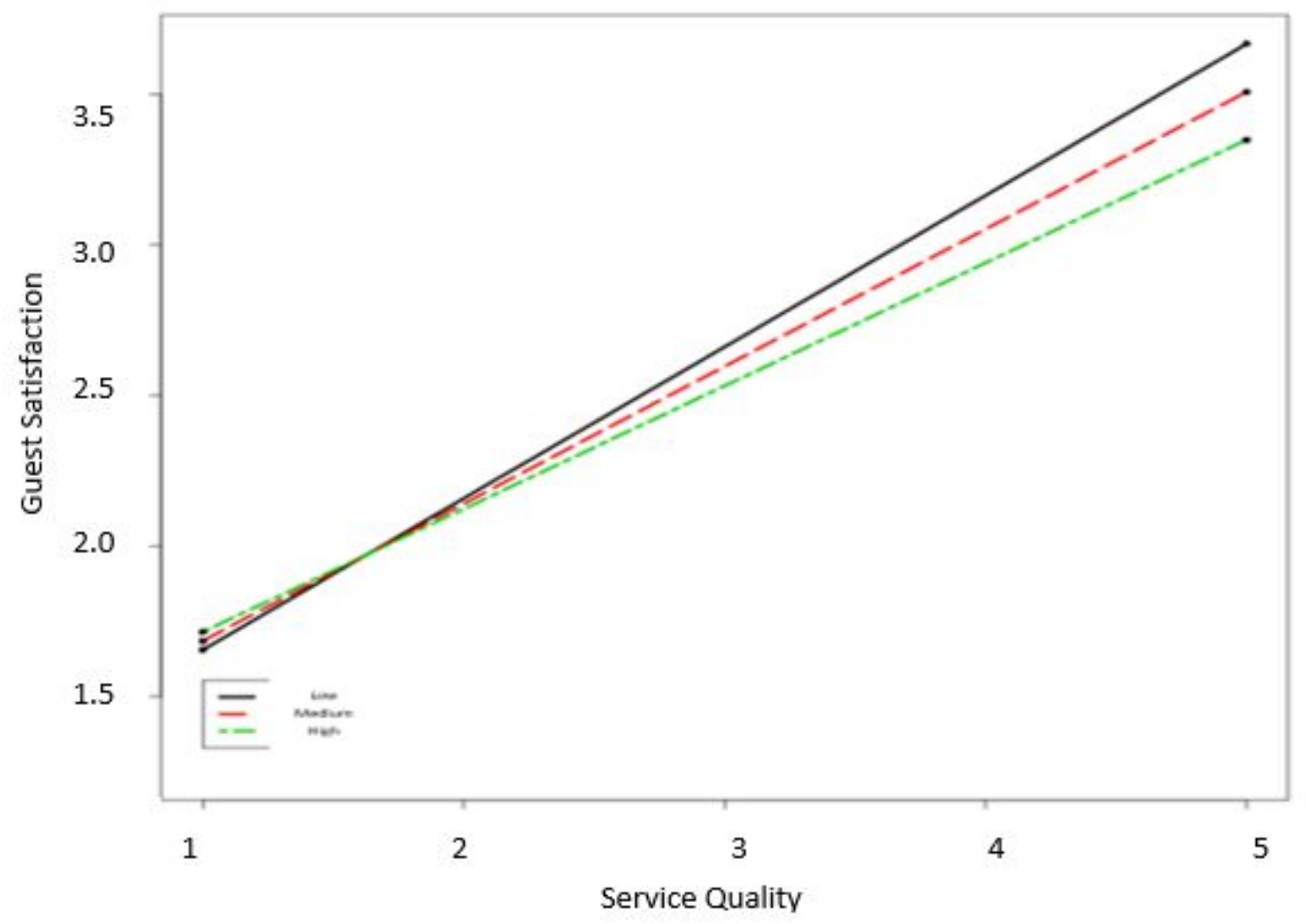


Table I: Interaction effect of hotel star rating with value for money, service quality on guest satisfaction (Regression 1)

\begin{tabular}{|c|c|c|c|c|c|c|}
\hline \multirow[t]{2}{*}{ Variables } & \multicolumn{2}{|l|}{ Model 1} & \multicolumn{2}{|l|}{ Model 2} & \multicolumn{2}{|l|}{ Model 3} \\
\hline & $\beta$ (Leisure) & $\beta$ (Business) & $\beta$ (Leisure) & $\beta$ (Business) & $\beta$ (Leisure) & $\beta$ (Business) \\
\hline Origin country & $.085^{*}$ & $.041 *$ & & & & \\
\hline Travel frequency & $.054 *$ & $.134 * * *$ & & & & \\
\hline Value for money & $.502 * * *$ & $.390 * * *$ & & & & \\
\hline Service quality & $.398^{* * *}$ & $.472 * * *$ & & & & \\
\hline Origin country & & & $.072 *$ & .019 & & \\
\hline Travel frequency & & & .030 & $.092 * *$ & & \\
\hline Value for money & & & $.524 * * *$ & $.400 * * *$ & & \\
\hline Service quality & & & $.424 * * *$ & $.513 * * *$ & & \\
\hline Hotel star rating & & & $.185 * * *$ & $.125^{*}$ & & \\
\hline Origin country & & & & & .039 & .012 \\
\hline Travel frequency & & & & & .028 & $.069^{*}$ \\
\hline Value for money & & & & & $.546^{* * *}$ & $.462 * * *$ \\
\hline Service quality & & & & & $.439 * * *$ & $.556^{* * *}$ \\
\hline Hotel star rating & & & & & $.109 * * *$ & $.065 * * *$ \\
\hline Value for money $*$ & & & & & $-.095 * * *$ & -.172 \\
\hline Hotel star rating & & & & & & \\
\hline Service quality * Hotel & & & & & $.061^{*}$ & $-.030 *$ \\
\hline star rating & & & & & & \\
\hline $\mathrm{R}^{2}$ & .791 & .699 & $.821 * * *$ & $.704 * *$ & $.865^{* * *}$ & $.723 * *$ \\
\hline
\end{tabular}

Dependent Variable: Guest Satisfaction

$* * * \mathrm{p}<.001 ; * * \mathrm{p}<.01 ; * \mathrm{p}<.05$ 
Table II: Interaction effect of hotel star rating with value for money, service quality on WOM (Regression 2)

\begin{tabular}{|c|c|c|c|c|c|c|c|c|}
\hline \multirow[t]{2}{*}{ Variables } & \multicolumn{2}{|l|}{ Model 1} & \multicolumn{2}{|l|}{ Model 2} & \multicolumn{2}{|l|}{ Model 3} & \multicolumn{2}{|l|}{ Model 4} \\
\hline & $\beta$ (Leisure) & $\beta$ (Business) & $\beta$ (Leisure) & B (Business) & $\beta$ (Leisure) & $\beta$ (Business) & $\beta$ (Leisure) & $\beta$ (Business) \\
\hline $\begin{array}{l}\text { Origin country } \\
\text { Travel frequency } \\
\text { Value for money } \\
\text { Service quality }\end{array}$ & $\begin{array}{l}0.12(0.19) \\
0.49(1.63) \\
2.04 * * *(56.7) \\
1.16^{* * *}(24.9)\end{array}$ & $\begin{array}{l}0.35(0.89) \\
1.21 * * *(32.8) \\
1.57 * * *(47.2) \\
0.99 * * *(7.5)\end{array}$ & & & & & & \\
\hline $\begin{array}{l}\text { Origin country } \\
\text { Travel frequency } \\
\text { Value for money } \\
\text { Service quality } \\
\text { Hotel star rating }\end{array}$ & 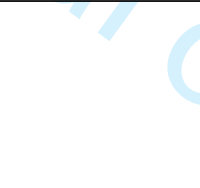 & & $\begin{array}{l}.12(.17) \\
0.53(1.83) \\
2.17 * * *(59.6) \\
1.23 * * *(27.2) \\
0.26(.94)\end{array}$ & $\begin{array}{l}0.52(1.2) \\
0.98^{* *}(24.7) \\
1.65^{* * *}(50.2) \\
0.97^{* *}(8.14) \\
0.36(1.77)\end{array}$ & & & & \\
\hline $\begin{array}{l}\text { Origin country } \\
\text { Travel frequency } \\
\text { Value for money } \\
\text { Service quality } \\
\text { Hotel star rating } \\
\text { Value for money * } \\
\text { Hotel star rating } \\
\text { Service quality * Hotel } \\
\text { star rating }\end{array}$ & & & & & $\begin{array}{l}.08(0.12) \\
.32(0.92) \\
1.75 * * *(50.1) \\
0.74(2.7) \\
0.20(.27) \\
-0.39(1.6) \\
0.84 *(20.2)\end{array}$ & $\begin{array}{l}0.17(0.30) \\
0.67(2.4) \\
2.34 * * *(63.1) \\
1.24 * * *(27.9) \\
0.20(0.26) \\
-0.19(0.18) \\
-0.33(.46)\end{array}$ & & \\
\hline $\begin{array}{l}\text { Origin country } \\
\text { Travel frequency } \\
\text { Value for money } \\
\text { Service quality } \\
\text { Hotel star rating } \\
\text { Value for money* Hotel } \\
\text { star rating } \\
\text { Service quality* Hotel } \\
\text { star rating } \\
\text { Customer satisfaction }\end{array}$ & & & & & & & $\begin{array}{l}-0.23(0.45) \\
0.32(0.09) \\
1.74 * * *(51.0) \\
1.16^{* * *}(26.5) \\
0.21(0.32) \\
-0.54(1.9) \\
0.91 *(20.1) \\
1.98 * * *(50.1)\end{array}$ & $\begin{array}{l}0.17(0.28) \\
0.66(2.4) \\
2.28 * * *(61.8) \\
0.65(2.3) \\
0.20(0.28) \\
-0.37(0.35) \\
-0.41(0.53) \\
1.29 * * *(32.9)\end{array}$ \\
\hline $\mathrm{R}^{2}$ & .369 & .383 & $.397 *$ & $.399 *$ & $.424 *$ & $.409 *$ & $.473 * *$ & $.432 *$ \\
\hline
\end{tabular}

Number is parentheses are odds ratio.

Dependent variable: Word of Mouth

$* * * \mathrm{p}<.001 ; * * \mathrm{p}<.01 ; * \mathrm{p}<.05$ 